\title{
PERAN AGAMA DALAM MASYARAKAT MULTIKULTURAL
}

\author{
Siti Rohmaniah \\ UIN Sunan Kalijaga Yogyakarta \\ sitirochmaniah93@gmail.com
}

\begin{abstract}
Multiculturalism is the recognition that different cultures can exist in the same environment and benefit each other. Multicultural societies have become a special character of the nation more specifically in Indonesian society, and have been discussed in various activities, seminars, discussion forums and in academic environment. Multicultural society is a society consisting of several kinds of cultural communities with all its advantages, with little difference in the conception of the world, a system of meaning, values, forms of social organization, history, customs and habits The role of religion will constructively make religious ties more stringent, often even exceeding the bondage of blood and nasab or ductility relationships. Then because of religion, a community or society will live in unified harmony and peace and unity. Conversely, destructively, religion also has destructive power, destroys unity and can even break the bond of unity. It makes a conflict with a religious background difficult to predict the end. The religion has the potential to generate an internal and external conflicts that ultimately can harm the community itself.
\end{abstract}

Key words: Religion, Multicultural Society

\begin{abstract}
Abstrak
Multikulturalisme merupakan pengakuan bahwa beberapa kultur yang berbeda dapat eksis dalam lingkungan yang sama dan menguntungkan satu sama lain. Masyarakat multikultural telah menjadi cri khas bangsa lebih khusus pada masyarakat Indonesia, dan telah diperbincangkan dalam berbagai kegiatan, seminar, forum diskusi maupun dalam lingkungan akademik. Masyarakat multikultural adalah suatu masyarakat yang terdiri dari beberapa macam komunitas budaya dengan segala kelebihannya, dengan sedikit perbedaan konsepsi mengenai dunia, suatu sistem arti, nilai, bentuk organisasi sosial, sejarah, adat serta kebiasaan Peran agama secara konstruktif akan membuat ikatan agama menjadi lebih ketat, bahkan sering melebihi ikatan darah dan hubungan nasab atau ketururnan. Maka karena agama, sebuah komunitas atau masyarakat akan hidup dalam kerukunan dan kedamaian yang utuh dan bersatu. Sebaliknya, secara destruktif, agama juga mempunyai kekuatan merusak, memporak-porandakan persatuan dan bahkan dapat memutus ikatan tali persatuan. Hal tersebut menjadikan suatu konflik yang berlatar belakang agama sulit diprediksi kesudahannya.Maka agama memiliki potensi untuk menimbulkan suatu konflik internal maupun eksternal yang akhirnya dapat merugikan masyarakat itu sendiri.
\end{abstract}

Kata Kunci: Agama, Masyarakat Multikultural

\section{Pendahuluan}

Dalam menjalani kehidupan di dunia ini agama memiliki posisi dan peranan yang sangat penting. Agama dapat berfungsi sebagai faktor motivasi (pendorong untuk bertindak yang benar, baik, etis, dan maslahat), profetik (menjadi risalah yang menunjukan arah kehidupan), kritik (menyuruh pada yang ma'ruf dan mencegah dari yang mungkar), kreatif (mengarahkan amal atau tindakan yang menghasilkan manfaat bagi diri sendiri dan orang lain), intergratif 
(menyatukan elemen-elemen yang rusak dalam diri manusia dan masyarakat untuk menjadi lebih baik), sublimatif (memberikan proses penyucian diri dalam kehidupan), dan liberatif (membebaskan manusia dari berbagai belenggu kehidupan). ${ }^{1}$ Agama sebagai suatu bentuk kepercayaan, diyakini manusia sebagai sistem nilai yang harus diejawantahkan ke dalam perilaku sosial tertentu. Ia berkaitan dengan pengalaman historis manusia, baik sebagai individu maupun kelompok.

Di dalam sebuah masyarakat, agama menjadi salah satu faktor penunjang kehidupan terutama dalam kehidupan spiritual. Walaupun tidak menutup kemungkinan di kemudian hari agama menjadi tradisi yang bercampur dengan kebiasaan lama yang telah hidup dalam suatu masyarakat. Kebiasaan tersebut diwarisi secara turun-temurun sehingga tidak mudah untuk dihilangkan begitu saja. Di sisi lain, agama datang belakangan dengan membawa nilai-nilai baru yang menuntut penganutnya menaati sebuah perintah dan menjauhi larangannya.

Joachim Watch mengemukakan adanya hubungan interdependensi dialektis antara agama dan masyarakat. Dengan kata lain, agama berpengaruh besar terhadap pembentukan dan pengembangan masyarakat, dan masyarakat dapat pula memberikan nuansa, rasa, dan sikap keagamaan spesifik yang terdapat dalam suatu lingkungan atau kelompok sosial. ${ }^{2}$

Indonesia merupakan sebuah negara yang terbentuk dari berbagai macam suku, ras, etnik, agama serta budaya. Kekuatan yang majemuk tersebut tentunya dapat menjadi sebuah kekuatan sosial dan sebuah kumpulan yang indah apabila antara satu dengan yang lainnya dapat saling bahu-membahu, saling bekerjasama untuk dapat membangun negara. Namun dilain pihak, kemajemukan tersebut akan menjadi sebuah kekuatan penghancur dari dalam apabila keragaman yang ada tidak dibina dan dikelola secara tepat. Keragaman kultur dan agama yang menjadi latar belakang dan menjadi suatu mozaik yang indah bagi negeri ini, yang sudah ada semenjak negara ini dilahirkan dapat memicu konflik dan kekerasan yang dapat menggoyahkan dan menghancurkan sendi-sendi kehidupan negara Indonesia. Masalah tersebut semakin mengkristal ketika dikaitkan dengan fenomena meletusnya berbagai kerusuhan bernuansa suku, agama, ras dan antar golongan (SARA) dalam beberapa tahun terakhir semenjak $1996 .^{3}$

Indonesia dengan memiliki berbagai macam suku, ras, etnik, agama secara sederhana dapat disebut sebagai masyarakat multikultural. Multikulturalisme

${ }^{1}$ Ali Imran, "Peranan Agama dalam Perubahan Sosial Masyarakat", Hikmah, Vol. II, No. 1 (Januari-Juni 2015), 2

2 Ridwan Lubis, Cetak Biru Peran Agama Merajut Kerukunan, Kesetaraan Gender dan Demokratisasi Dalam Masyarakat Multikultura, (Jakarta: Puslitbang Kehidupan Beragama, 2005), h.xi.

${ }_{3}^{3}$ Abdullah Idi, Revitalisasi Pendidikan Islam, (Yogyakarta: Tiara Wacana, 2006), h. 119. 
secara sederhana dapat dipahami sebagai pengakuan, bahwa sebuah negara atau masyarakat adalah beragam dan majemuk. ${ }^{4}$

Multikulturalisme meliputi sebuah penilaian terhadap budaya-budaya orang lain, bukan dalam arti menyetujui seluruh aspek dari budaya-budaya tersebut, melainkan mencoba melihat bagaimana sebuah budaya yang asli dapat mengekspresikan nilai bagi anggota-anggotanya sendiri. Namun, multikulturalisme bukan merupakan cara pandang yang menyamakan kebenaran-kebenaran lokal, melainkan justru mencoba membantu pihak-pihak yang berbeda untuk dapat membangun sikap saling menghormati satu sama lan terhadap perbedaan-perbedaan dan kemajemukan yang ada, agar tercipta perdamaian dan dengan demikian kesejahteraan dapat dinikmati oleh seluruh umat manusia.

Bagi masyarakat yang bisa memahami keberadaan agama dari segi sosiohistoris, ajaran agama yang telah melahirkan tradisi baru dalam masyarakat tersebut merupakan bukti bahwa agama tidak menolak tradisi secara keseluruhan. Sebaliknya agama bisa memberikan ruang kepada nilai-nilai lokal yang dianggap baik. Lalu bagaimana seharusnya hubungan antara agama dan tradisi yang hidup dalam masyarakat, khususnya warga negara Indonesia yang kaya akan tradisi dan budaya? Artikel ini akan mencoba membahas permasalahan peran agama dalam masyarakat multikultural.

\section{Pembahasan}

\section{Definisi Multikultural}

Secara etimologis multikultural terdiri atas kata multi yang berarti plural, kultural yang berarti kebudayaan. Secara umum kata 'multi' diartikan sebagai suatu yang jamak. Sedangkan kata 'kultural' berasal dari bahasa Inggris dari kata culture yang padanan kata dalam bahasa Indonesia ialah budaya. Budaya berasal dari bahasa Sansekerta, merupakan gabungan kata dari 'budhi' dan 'daya' yang berarti budi atau akal. Budaya menurut P.J. Zoetmulder sebagaimana yang dikutip oleh Koentjaraningrat adalah segala hasil dari segala cipta karsa dan rasa. ${ }^{5}$

Multikulturalisme merupakan pengakuan bahwa beberapa kultur yang berbeda dapat eksis dalam lingkungan yang sama dan menguntungkan satu sama lain. Atau pengakuan dan promosi terhadap pluralisme kultural. Sedang yang lain menyebutkan bahwa multikulturalisme menghargai dan berusaha melindungi keragaman kultural. ${ }^{6 S e d a n g}$ Suryadinata menyebutkan bahwa multikulturalisme menghargai dan berusaha melindungi keragaman kultural.Multikulturalisme bukanlah sebuah doktrin politik pragmatis, ia adalah sebuah cara pandang kehidupan manusia (paradigma).

4Zakiyuddin Baidhawy, Pendidikan Agama Berwawasan Multikultural, (Jakarta: Erlangga, 2005), h. vii.

${ }^{5}$ Koentjaraningrat, Pengantar Antopologi (Jakarta: Aksara Baru, 1982), h. 80.

${ }^{6}$ Choirul Mahfud, Pendidikan Multikultural (Yogyakarta: Pustaka Pelajar, 2006), h. 75. 
Istilah "multibudaya" (multiculture) jika ditelaah asal-usulnya mulai dikenal sejak tahun 1960-an, setelah adanya gerakan hak-hak sipil sebagai koreksi terhadap kebijakan asimilasi kelompok minoritas terhadap melting pot $^{7}$ yang sudah berjalan lama tentang kultur dominan Amerika khususnya di New York dan California. ${ }^{8}$ Will Kymlicka berpendapat, multibudaya merupakan suatu pengakuan, penghargaan dan keadilan terhadap etnik minoritas baik yang menyangkut hak-hak universal yang melekat pada hak-hak individu maupun komunitasnya yang bersifat kolektif dalam mengekspresikan kebudayaannya. ${ }^{9}$

\section{Jenis Masyarakat Multikultural}

Menurut Parekh dalam bukunya National Culture and Multikulturalism yang dikutip oleh Chairul Mahfud, yang secara jelas membedakan multikulturalisme menjadi lima. Kelima macam tersebut adalah:

Pertama, multikulturalisme isolasionis yang mengacu kepada masyarakat dimana berbagai kelompok kultural menjalankan hidup secara otonom dan terlibat dalam interkasi yang hanya minimal satu sama lain. Kedua, multikulturalisme akomodatif, yakni masyarakat plural yang memiliki kultur dominan, yang membuat penyesuaian dan akomodasi-akomodasi bagi kebutuhan kultural kaum minoritas.Multikultural ini dapat ditemukan di Inggris, Prancis dan beberapa negara Eropa yang lain.

Ketiga, multikulturalisme otonomis, yakni masyarakat plural di mana kelompok-kelompok kultural utama berusaha mewujudkan kesetaraan dengan budaya dominan dan menginginkan kehidupan otonom dalam kerangka politik yang secara kolektif dapat diterima. Kepedulian pokok kelompok-kelompok kultural terakhir ini adalah untuk mempertahankan cara hidup mereka, yang memiliki hak yang sama dengan kelompok yang dominan. Mereka menentang kelompok kultural dominan dan berusaha menciptakan suatu masyarakat di mana semua kelompok dapat eksis sebagai mitra belajar.

Keempat, multikulturalisme kritikal atau interaktif, yakni masyarakat plural di mana kelompok-kelompok tidak terlalu peduli dengan kehidupan kultural otonom, tetapi lebih menuntut penciptaan kultur kolektif yang mencerminkan dan menegaskan perspektif-perspektif distingtif mereka.

${ }^{7}$ Lebih jauh Alo Liliweri menjelaskan bahwa banyak budaya hidup di daerah-daerah perbatasan antar Negara, antar-suku bangsa, antar-etnik, antarras, dan antar-geografis. Di sinilah muncul situasi dan kondisi masyarakat yang memiliki keragaman budaya. Kita menggunakan istilah methaphors untuk menggambarkan kebudayaan campuran (mixed culture). Ada beberapa istilah yang menggunakan methapor di antaranya yaitu melting pot adalah masyarakat masih memelihara keunikan budaya untuk membedakan keturunan mereka dengan orang lain. Dalam konsep ini masing-masing etnis dengan budayanya menyadari adanya perbedaan antara sesamanya. Namun, dengan perbedaan tersebut mereka dapat membina hidup bersama dengan baik dan sehat. $\mathrm{H}$ ini dapat ditafsirkan bahwa melting pot terdapat kekuatan untuk mensintesiskan kebudayaan dari masing-masing kelompok. 164.

8 James Banks, Teaching Strategies For Ethnic Studies, (Newton: Allyn and Bacon, 1984), h

${ }^{9}$ Will, Kymlicka, “Mitsunderstanding Nationalism" dalam Theorizing Nationalism, ed. R. Beiner, (Albany: State University of New York, 1999), h 24 
Multikultural ini, berlaku di Amerika Serikat dan Inggris perjuangan kulit hitam dalam menuntut kemerdekaan.

Kelima, multikulturalisme kosmopolitan, yakni paham yang berusaha menghapuskan batas-batas kultural sama sekali untuk menciptakan sebuah masyarakat di mana setiap individu tidak lagi terikat kepada budaya tertentu. Sebaliknya, mereka secara bebas terlihat dalam eksperimen-eksperimen interkultural dan sekaligus mengembangkan kehidupan kultural masingmasing. ${ }^{10}$

\section{Ciri-ciri Masyarakat Multikultural}

Ciri-ciri yang menyolok dan kritikal dari masyarakat majemuk adalah hubungan antara sistem nasional atau pemerintah nasional dengan masyarakat suku bangsa, dan hubungan di antara masyarakat suku bangsa yang dipersatukan oleh sistem nasional. Dalam perspektif hubungan kekuatan, sistem nasional atau pemerintahan nasional adalah yang dominan dan masyarakatmasyarakat suku bangsa dalam amsyarakat jajahan selalu diperantarai oleh golongan perantara, yang posisi ini di hindia Belanda dipegang oleh golongan Cina, Arab, dan Timur Asing lainnya untuk kepentingan pasar. Sedangkan para sultan dan raja atau para bangsawan yang disukung oleh para birokrat (priyayi) digunakan untuk kepentingan pemerintahan dan penguasaan. Atau dipercayakan kepada para bangsawan dan priyayi untuk kelompok-kelompok suku bangsa yang digolongkan sebagai terbelakang atau primitif.11

\section{Penyebab Timbulnya Masyarakat Multikultural di Indonesia}

Kenyataan bahwa Indonesia adalah bangsa yang sangat beragam merupakan fakta yang tidak bisa dipungkiri oleh siapa pun. Keragaman Indonesia tidak saja tercermin dari banyaknya pulau yang dipersatukan di bawah satu kekuasaan negara, melainkan juga keragaman warna kulit, bahasa, etnis agama dan budaya.Karena itu yang menjadi persoalan bukanlah kenyataan bahwa bangsa ini adalah amat beragam (yang memang tak bisa disangkal), melainkan cara kita memandang dan mengelolakeragaman tersebut. Secara umum, faktor penyebab timbulnya masyarakat multikultural adalah:

\section{Keadaan Geografis}

Keadaan geografis wilayah Indonesia yang terdiri lebih dari 17 ribu pulau dan tersebar di suatu daerah equator sepanjang kurang lebih 300 mil dari timur ke barat dan lebih dari 1000 mil utara ke selatan, merupakan faktor yang sangat besar pengaruhnya terhadap tercapainya multikultural suku bangsa di Indonesia. Pendatang terutama di kepulauan Indonesia sekitar 20.000 tahun yang lalu.

${ }^{10}$ Choirul Mahfud, Pendidikan Multikultural...h.93-94.

${ }^{11 N u r ~ H i d a y a h, ~ M a s y a r a k a t ~ M u l t i k u l t u r a l . h .4 . ~}$ 
Menyusul kemudian Ras Melanesean Negroid pada sekitar 10.000 tahun yang lalu. Kehadiran ras-ras itu terjadi pada zaman Mesolithicur. Terakhir datang Ras Malayan Mongoloid melalui 2 periode, zaman Neolitikum dan zaman logam, sekitar tahun 2500 tahun sebelum Masehi. Ras Austroloid kemudian pergi ke Australia dan sisa-sisanya ada di Nusa Tenggara Timur dan Papua, sedangkan Ras Melanesian Negroid tinggal di Maluku dan Papua. Kemudia Ras Malayan Mongoloid tinggal di Indonesia bagian barat. Ras-ras tersebut yang kemudian disebut bangsa Indonesia dalam bentuk keanekaragaman suku bangsa setelah melalui proses amal gamasi dan isolasi.

Kondisi geografis yang telah mengisolir penduduk yang menempati pulau dan daerah menumbuhkan kesatuan suku bangsa yang berbeda-beda. Mereka mengembangkan mitos-mitos tentang asul-usul keturunan dan nenek moyangnya.

\section{Letak Wilayah yang Strategis}

Letak Indonesia yang strategis antara Samudra Hindia dan Pasifik sangat memengaruhi proses multikultural, seperti unsur kebudayaan dan agama. Kepulauan Indonesia merupakan jalur lalu lintas perdagangan antara India, Cina dan wilayah Asia Tenggara. Melalui para pedagang asing pengaruh kebudayaan dan agama masuk ke wilayah Indonesia. Daerah penyeberan kebudayaan dan agama yang tidak merata menyebabkanterjadinya proses multikultural unsur kebudayaan dan agama. Pengaruh agama dan kebudayaan Hindu-Budha pada awal tarikh Masehi hanya berkembang di wilayah Indonesia barat. Pengaruh kebudayaan Cina terutama hanya terjadi di daerah pantai dan kota-kota dagang. Pengaruh kebudayaan Cina terutama hanya terjadi di daerah pantai dan kota-kota dagang. Pengaruh ajaran Islam berkembang pada abad ke-13, terutama di Indonesia bagian barat dan sebagian dari Maluku. Pengaruh kolonial Portugis dengan Agama Katoliknya terjadi terutama di wilayah Nusa Tenggra Timur. Pada abad ke-16 Belanda datang dan pada abad ke-17 mengembangkan Agama Kristen dan Katolik di beberapa daerah di Sumatera, Kalimantan, Sulawesi, Maluku, Papua dan kota-kota besar di Jawa.

\section{Kondisi Iklim yang Berbeda}

Wilayah lingkungan hidup suku-suku bangsa juga memperlihatkan variasi yang berbeda-beda. Ada komunitas yang mengandalkan laut sebagai sumber kehidupannya, seperti orang laut di Kepulauan Riau, orang Bajo di Sulawesi Selatan dan Asmat di Papua. Karakter multikultural ditambah lagi dengan perbedaan-perbedaan tipe masyarakatnya terlihat pada komunitas kosmopolitan perkotaan, komunitas peralihan dari pertanian ke industri dan sebagian lainnya masih mencirikan komunitas berbudaya suku bangsa (tribal communites). 
Perbedaan curah hujan dan kesuburan tanah merupakan kondisi yang menciptakan dua macam lingkungan ekologis yang berbeda di Indonesia, yakni daerah pertanian sawah (wet rice cultivation) yang banyak dijumpai di pulau Jawa dan Bali serta daerah pertanian ladang (shifting cultivation) yang banyak kita jumpai di luar Pulau Jawa. Perbedaan lingkungan ekologis tersebut menyebabkan terjadinya perbedaan antara Jawa dan luar Jawa dalam bidang kependudukan, ekonomi, sosial dan budaya. Sistem pertanian sawah di Jawa mendorong tumbuhnya suatu tertib kemasyarakatan yang mendasarkan diri pada kekuaasan di daratan.

Sedangkan sistem pertanian ladang di luar Jawa mendorong tumbuhnya sistem kemasyarakatan yang mendasarkan diri pada kekuasaan di lautan sehingga memiliki keunggulan dalam perdagangan. Apabila di Jawa pernah tumbuh kekuasaan Mataram kuno dan Majapahit yang gemilang maka di luar Jawa pun pernah berkembang kerajaan Melayu dan Sriwijaya yang cemerlang. Berkaitan dengan ini, Ibnu Khaldun menulis khusus satu bab tentang korelasi peradaban dengan kondisi kesuburan tanah dan kelaparan serta pengaruhnya terhadap tubuh dan perbuatan manusia. ${ }^{12}$

\section{Multikulturalisme di Indonesia}

Masyarakat Indonesia merupakan masyarakat dengan tingkat keanekaragaman yang sangat kompleks. Masyarakat dengan berbagai keanekaragaman tersebut dikenal dengan istilah mayarakat multikultural. Bila kita mengenal masyarakat sebagai sekelompok manusia yang telah cukup lama hidup dan bekerja sama sehingga mereka mampu mengorganisasikan dirinya dan berfikir tentang dirinya sebagai satu kesatuan sosial dengan batas-batas tertentu (Linton), maka konsep masyarakat tersebut jika digabungkan dengan multikurtural memiliki makna yang sangat luas dan diperlukan pemahaman yang mendalam untuk dapat mengerti apa sebenarnya masyarakat multikultural itu.

Multikultural dapat diartikan sebagai keragaman atau perbedaan terhadap suatu kebudayaan dengan kebudayaan yang lain. Sehingga masyarakat multikultural dapat diartikan sebagai sekelompok manusia yang tinggal dan hidup menetap di suatu tempat yang memiliki kebudayaan dan ciri khas tersendiri yang mampu membedakan antara satu masyarakat dengan masyarakat yang lain. Setiap masyarakat akan menghasilkan kebudayaannya masing-masing yang akan menjadi ciri khas bagi masyarakat tersebut.

Dari sinilah muncul istilah multikulturalisme. Banyak definisi mengenai multikulturalisme, diantaranya multikulturalisme pada dasarnya adalah pandangan dunia -yang kemudian dapat diterjemahkan dalam berbagai

12Rizal Mubit, "Peran Agama Dalam Multikulturalisme Masyarakat Indonesia, Epistemé, Vol. 11, No. 1, Juni 2016. 
kebijakan kebudayaan- yang menekankan tentang penerimaan terhadap realitas keragaman, pluralitas, dan multikultural yang terdapat dalam kehidupan masyarakat. Multikulturalisme dapat juga dipahami sebagai pandangan dunia yang kemudian diwujudkan dalam "politics of recognition" (Azyumardi Azra, 2007). Lawrence Blum mengungkapkan bahwa multikulturalisme mencakup suatu pemahaman, penghargaan, dan penilaian atas budaya seseorang, serta penghormatan dan keingintahuan tentang budaya etnis orang lain. Berbagai pengertian mengenai multikulturalisme tersebut dapat ddisimpulkan bahwa inti dari multikulturalisme adalah mengenai penerimaan dan penghargaan terhadap suatu kebudayaan, baik kebudayaan sendiri maupun kebudayaan orang lain. Setiap orang ditekankan untuk saling menghargai dan menghormati setiap kebudayaan yang ada di masyarakat. Apapun bentuk suatu kebudayaan harus dapat diterima oleh setiap orang tanpa membeda-bedakan antara satu kebudayaan dengan kebudayaan yang lain.

Pada dasarnya, multikulturalisme yang terbentuk di Indonesia merupakan akibat dari kondisi sosio-kultural maupun geografis yang begitu beragam dan luas. Menurut kondisi geografis, Indonesia memiliki banyak pulau di mana setiap pulau tersebut dihuni oleh sekelompok manusia yang membentuk suatu masyarakat. Dari masyarakat tersebut terbentuklah sebuah kebudayaan mengenai masyarakat itu sendiri. Tentu saja hal ini berimbas pada keberadaan kebudayaan yang sangat banyak dan beraneka ragam.

\section{Peran Agama dalam Masyarakat Multikultural}

Agama, dalam perspektif sosiologis menurut Casram, memiliki peran dan fungsi ganda, baik yang bersifat konstruktif maupun destruktif. Maksudnya adalah, peran agama secara konstruktif akan membuat ikatan agama menjadi lebih ketat, bahkan sering melebihi ikatan darah dan hubungan nasab atau ketururnan. Maka karena agama, sebuah komunitas atau masyarakat akan hidup dalam kerukunan dan kedamaian yang utuh dan bersatu. Sebaliknya, secara destruktif, agama juga mempunyai kekuatan merusak, memporak-porandakan persatuan dan bahkan dapat memutus ikatan tali persatuan. Hal tersebut menjadikan suatu konflik yang berlatar belakang agama sulit diprediksi kesudahannya.

Terlepas dari fungsi ganda di atas, setiap manusia yang hidup di tengahtengah masyarakat multiagama pasti mendambakan suasana damai dan rukun. Kehidupan sosial masyarakat yang terbentuk atas dasar multikultural dan memiliki semangat hidup damai dalam kemajemukan akan menjadi mungkin apabila semua masyarakat mampu mengakomodasi perbedaan dan keragaman tersebut, sehingga toleransi agama menjadi sebuah keniscayaan sebagai upaya untuk menjamin stabilitas sosial dari tuntutan ideologis ini. Kehidupan sosial dan agama hendaknya tidak tersisih satu sama lain dan musti terintegrasi ke dalam satu kesatuan yang utuh. 
Agama yang sudah masuk dalam masyarakat multikultural akan mengalami proses akulturasi sehingga agama bisa memiliki banyak versikhususnya dalam aspek implementasi. Mulai dari segi pemahaman sampai pada arti penting agama sesuai dengan kultur masing-masing daerah atau tempat. Dari masyarakat multikultural inilah lahir perbedaan ekspresi dalam melaksanakan perintah agama.

Peranan menjadi sangat penting ketika agama telah dianut oleh kelompokkelompok sosial manusia, yang terkait dengan pemenuhan kebutuhan hidup manusia yang kompleks dalam masyarakat. Pada perkembangan yang demikian itulah agama menjadi berkaitan langsung dengan kebudayaan dalam masyarakat sehingga agama dan masyarakat serta kebudayaan mempunyai hubungan timbal balik yang saling berpengaruh. ${ }^{13}$

Sampai batas tertentu, respons agama terhadap kecenderungan multikulturalisme memang masih terkesan ambigu. Hal itu disebabkan, agama kerap dipahami sebagai wilayah sakral, metafisik, abadi, samawi dan mutlak. Bahkan, pada saat agama terlibat dengan urusan 'duniawi' sekalipun, hal ini tetap demi penunaian kewajiban untuk kepentingan 'samawi.' Berbagai agama, tentu saja, berbeda-beda dalam perkara cara dan berbagai aspeknya, namun agama-agama tersebut hampir seluruhnya memiliki sifat-sifat demikian itu. ${ }^{14 K a r e n a}$ sakral dan mutlak maka sulit bagi agama-agama tersebut untuk mentoleransi atau hidup berdampingan dengan tradisi kultural yang dianggap bersifat duniawi dan relativistik. Oleh karena itu, persentuhan agama dan budaya lebih banyak memunculkan persoalan daripada manfaat. Apalagi, misalnya dalam konteks Islam, kemudian dikembangkan konsep bid'ah yang sama sekali tidak memberikan ruang akomodasi bagi penyerapan budaya nonagama.

Perbedaan-perbedaan yang ada seharusnya disikapi sebagai kekayaan bangsa dimana para penganut agama yang berbeda bisa saling menghargai, saling menghormati, saling belajar, saling menimba, serta memperkaya dan memperkuat nilai-nilai keagamaan masing-masing.

Perbedaan tidak perlu dipertentangkan, tetapi dilihat dan dijadikan sebagai pembanding, pendorong, bahkan penguat dan pemurni apa yang dimiliki. Kaum beriman dan penganut agama yang berbeda-beda semestinya bisa hidup bersama dengan rukun dan damai, bisa bersatu, saling membantu dan saling mengasihi.

Keberadaan agama merupakan pondasi, langkah awal, dan inisiasi demi terciptanya masyarakat yang bermoral. Moral inilah yang kemudian mampu menstimulasi insting dan nurani manusia menjadi makhluk yang beradab

\footnotetext{
13Parsudi Suparlan, "Kesetaraan Warga dan Hak Budaya Komuniti dalam Masyarakat Majemuk Indonesia" dalam Jurnal Antropologi Indonesia, 2002, h.13.

14Mun'im A. Sirry, “Agama, Demokrasi dan Multikulturalisme”, dalam Kompas, 1 Mei 2003.
} 
sehingga pada akhirnya dapat terealisasikan kegiatan berbangsa dan bernegara yang adil dan makmur.

Dalam upaya membangun hubungan sinergi antara multikulturalisme dan agama, minimal diperlukan dua hal. Pertama, penafsiran ulang atasdoktrindoktrin keagamaan ortodoks yang sementara ini dijadikan dalih untuk bersikap eksklusif dan opresif. Penafsiran ulang itu harus dilakukan sedemikian rupa sehingga agama bukan saja bersikap reseptif terhadap kearifan tradisi lokal, melainkan juga memandu di garda depan untuk mengantarkan demokrasi builtin dalam masyarakat-masyarakat beragama.

Di sisi lain, kerancuan atau pemaknaan sepotong-potong atas doktrin keagamaan juga berdampak pada timbulnya sikap pengagungan terhadap kitab suci atau sering disebut skripturalisme. Menurut Ulil Abshar Abdalla, skripturalisme bisa disebut juga dengan "bibliolatry" atau secara terminologi berarti "pengagungan" kitab suci apa pun secara berlebihan sehingga menyerupai penyembahan. Hal itu disebabkan oleh wawasan teologis yang bersifat "ultra-teosentris". Artinya, wawasan yang menganggap bahwa Tuhan berbicara langsung kepada manusia via Nabi; bahwa Sabda Tuhan, adalah superior terhadap manusia; bahwa Sabda Tuhan, sejauh tidak ada alasan-alasan yang kuat dan kokoh, harus dimengerti dalam pengertianya yang harfiah. Akhirnya teks ditempatkan pada kedudukan yang sentral dan supreme, sementara pengalaman manusia yang riil dan kontekstual diletakkan inferior, rendah, sekunder atau bahkan tak berarti sama sekali. ${ }^{15}$

Kedua, mendialogkan agama dengan gagasan-gagasan modern. Saat ini, umat beragama memasuki suatu fase sejarah baru di mana mereka harus mampu beradaptasi dengan peradaban-peradaban besar yang tidak didasarkan pada agama, seperti kultur Barat modern. Kita tak mungkin menghindar dari ide-ide dan teori-teori sekuler. Itu berarti, menyentuh istilah-istilah dengan gagasan nonreligius itu merupakan tugas paling menantang yang dihadapi kaum Muslim pada zaman modern ini. ${ }^{16}$

Namun masalah-masalah perbedaan di antara agama-agama yang ada adalah sebuah realitas, yang tidak dapat dipungkiri oleh siapapun. Perbedaan terjadi pada hampir semua aspek agama, baik di bidang konsepsi tentang Tuhan maupun konsepsi pengaturan kehidupan. Hal ini dalam prakteknya, cukup sering memicu konflik fisik antara umat berbeda agama.

Orang beragama yang tidak toleran terhadap agama atau orang beragama yang lain, pada dasarnya mencederai cita-cita agamanya sendiri serta menolak atau menolak kemajemukan agama dalam lingkungan masyarakatnya. Merusak kemajemukan agama dalam suatu masyarakat yang majemuk sama dengan menolak atau merusakkan eksistensi masyarakat itu sendiri.

15Rizal Mubit, “Peran Agama Dalam Multikulturalisme..h.179.

16Ibid...h.179. 
Agama sangat baik sekali dalam hal pembinaan masyarakat untuk menuju pada kesejahteraan dan sekaligus nurani masyarakat itu sendiri. Salah satu alasan mengapa demikian adalah pertama, agama mengajarkan nilai-nilai yang benar dan baik bagi umatnya. Agama memoles umatnya untuk menjadi individu-individu yang baik dan menjauhkannya dari segala sesuatu yang bertentangan dengan ajaran agamanya. Kedua, agama mengajarkan cara-cara untuk memperoleh tempat yang indah di akhirat nanti sebagai tujuan akhir kehidupan. Cara-cara ini berintikan pada pelaksanaan ajaran agama masingmasing dengan sungguh-sunguh. Orang yang melaksanakan dengan baik akan memeroleh tempat yang bernama surga, sedangkan orang yang tidak melaksanakannya akan memeroleh tempat yang berkebalikan dengan surga, yaitu neraka.

Ketiga, agama yang berfokus pada ajaran cinta kasih mengajak umatnya untuk mengasihi sesamanya sehingga antarsesama dapat saling menghargai dan saling tolong-menolong melalui institusi masing-masingyang biasanya diekspresikan dalam kegiatan-kegiatan sosial maupun keagamaan.

Keempat, secara tidak langsung agama mendorong terciptanya perdamaian di muka bumi yang terdiri atas masyarakat yang majemuk melalui ajaran-ajaran tersebut. Hal ini sejalan dengan seruan-Nya dalam al-Qur'an yang berbunyi, "Jika Allah menghendaki, Ia bisa menjadikan semua manusia sebagai satu bangsa $(5: 48 ; 11: 118)$. Selain itu, seruan untuk hidup bersama secara damai dan universal sebagaimana dalam dua ayat (60: 8-9) misalnya, adalah bukti autentik bahwa keragaman merupakan keniscayaan dan nash Tuhan. Sehingga sudah sepatutnya ayat-ayat tersebut menjadikan Muslim wajib bersikap toleran dan penuh damai sebagai sesama makhluk yang hidup di dunia berdasarkan kesetaraan (qisth) dan kebaikan utama (birr). ${ }^{17}$

Indonesia adalah negara beragama. Melalui penggeneralisasian masyarakat Indonesia sebagai pemeluk agama yang sah - tanpa membedakan apa agamanya - dengan mengansumsikan upaya-upaya pengaplikasian kebaikan secara represif seperti di atas berhasil dilakukan, tentu diversitas suku bangsa, etnik, dan budaya yang ada bukan menjadi masalah dan percik api perselisihan.

Apabila masyarakat Indonesia yang multikultural dan multietnik menghargai adanya multireligi, saling menghormati, dan menghargai perbedaan, tentu masalah-masalah antar agama tidak akan terjadi dan sebagai ganti, pada akhirnya akan tercipta masyarakat yang sejahtera, adil, dan makmur di tengah perbedaan. Betapa indahnya Negara Indonesia apabila demikian.

Pemerintah (sebagai penegak kerukunan beragama) serta masyarakat (sebagai subjek hidup beragama) harus senantiasa saling membahu dalam

17Jamal A. Badawi, "Hubungan Antaragama: Sebuah Perspektif Islam", dalam Franz Magnis Suseno, et.al., Memahami Hubungan Antaragama, terj. Burhanudin Dzikri (Yogyakarta: elSAQ Press, 2007), h. 155-156. 
mencermati dan mengevaluasi doktrin serta praktik-praktik keagamaan yang menyimpang, atau bahkan hanya formal dan ritualistik belaka, agar lebih fungsional atau berdaya-guna secara tepat dan efektif bagi pemantapan kualitas diri dan kehidupan penganutnya pada khususnya, maupun masyarakat pada umumnya.

Sebagai refleksinya, Bhinneka Tunggal Ika dapat berkiprah dan berkibar kembali di Bumi Pertiwi sehingga anggapan dunia tentang masyarakat Indonesia yang ramah dan memiliki tingkat toleransi tinggi menjadi kenyataan dan bukan sekadar bualan serta 'fitnah' belaka. Langkah-langkah ini harus diwujudkan dengan penuh kesadaran. Semoga semakin banyak umat beragama di Indonesia yang sadar.

\section{Kesimpulan}

Multikulturalisme merupakan pengakuan bahwa beberapa kultur yang berbeda dapat eksis dalam lingkungan yang sama dan menguntungkan satu sama lain. Masyarakat multikultural telah menjadi cri khas bangsa lebih khusus pada masyarakat Indonesia, dan telah diperbincangkan dalam berbagai kegiatan, seminar, forum diskusi maupun dalam lingkungan akademik.

Dalam masyarakat modern, multikulturalisme lebih kompleks lagi. Sebab budaya baru terus bermunculan akibat akses komunikasi dan informasi yang tak terbendung. Saat terjadi pertemuan antara globalisasi negara-bangsa (nationstate) dan kelompok identitas maka kemunculan dari kelompok-kelompok identitas ini semakin menguat. Globalisasi akan mendorong penguatan kesadaran politik dalam kelompok-kelompok ini dan membuka kesadaran yang mendorong pentingnya identitas. Globalisasi memberikan kesempatan kepada kelompok-kelompok identitas untuk menemukan akar identitasnya.

Pemahaman agama, sebagai salah satu pilar penting dalam membentuk masyarakat adil dan sejahtera menjadi penting untuk diperhatikan. Artinya, kerigidan, penuhanan atas pemahaman sendiri dan menganggap yang lain sebagai golongan sesat harus diberantas. Sebab pada hakikatnya tidak ada kebenaran apa pun yang menginjak dan meniadakan kebenaran lain.

\section{Referensi}

Abdullah Idi. Revitalisasi Pendidikan Islam. Tiara Wacana. Yogyakarta. 2006.

Ali Imran. "Peranan Agama dalam Perubahan Sosial Masyarakat", jurnal Hikmah, Vol. II, No. 12015.

Choirul Mahfud. Pendidikan Multikultural. Pustaka Pelajar. Yogyakarta. 2006.

Koentjaraningrat. Pengantar Antopologi. Aksara Baru. Jakarta. 1982.

Mun'im A. Sirry,. "Agama, Demokrasi dan Multikulturalisme", dalam Kompas. 2003

Parsudi Suparlan. "Kesetaraan Warga dan Hak Budaya Komuniti dalam Masyarakat Majemuk Indonesia" Jurnal Antropologi Indonesia. 2012. 
Ridwan Lubis. Cetak Biru Peran Agama Merajut Kerukunan, Kesetaraan Gender dan Demokratisasi Dalam Masyarakat Multikultural. Puslitbang Kehidupan Beragama. Jakarta. 2005.

Rizal Mubit. "Peran Agama Dalam Multikulturalisme Masyarakat Indonesia". Epistemé, Vol. 11, No. 1, Juni. 2016,

Will, Kymlicka, "Missunderstanding Nationalism" dalam Theorizing Nationalism, ed. R. Beiner, State University of New York. Albany. 1999

Zakiyuddin Baidhawy. Pendidikan Agama Berwawasan Multikultural. Erlangga. Jakarta. 2005. 